\title{
Selective synthesis of monoorganotin trihalides: the direct reaction of allylic halides with tin(II) halides catalyzed by platinum and palladium complexes
}

\author{
Sander Thoonen, ${ }^{\mathrm{a}}$ Berth-Jan Deelman ${ }^{\mathrm{b}, *}$ and Gerard van Koten ${ }^{\mathrm{a}}$ \\ a Department of Metal-Mediated Synthesis, Debye Institute, Utrecht University, Padualaan 8, 3584 CH Utrecht, The Netherlands \\ ${ }^{\mathrm{b}}$ ATOFINA Vlissingen B.V., PO Box 70, 4380 AB Vlissingen, The Netherlands
}

Received 16 April 2003; revised 18 September 2003; accepted 16 October 2003

\begin{abstract}
The reaction of 3-haloalkenes (3-chloropropene, 3-bromopropene, 3-chloro-2-methylpropene, 1-chloro-2-butene) with $\mathrm{SnX}{ }_{2}$ $(\mathrm{X}=\mathrm{Cl}, \mathrm{Br})$ to form mono-allyltin trihalides, was catalyzed by several platinum and palladium complexes of the type $\mathrm{MZ} \mathrm{Z}_{2} \mathrm{~L}(\mathrm{M}=\mathrm{Pt}, \mathrm{Pd}$; $\mathrm{Z}=\mathrm{Me}, \mathrm{Cl} ; \mathrm{L}=2,2^{\prime}$-bipyridine, 1,10-phenanthroline or dppe). The highest yield of allyltin trichloride was obtained for the reaction of 3-chloropropene with $\mathrm{SnCl}_{2}$ catalyzed by $\mathrm{PdMe}_{2}$ (phen) (83\%) while the yield obtained with the other catalysts decreased in the order $\mathrm{PdCl}_{2}$ (phen), $\mathrm{PdCl}_{2}$ (bipy) $>\mathrm{PdMe}_{2}$ (bipy) $>\mathrm{PtCl}_{2}$ (phen) $>\mathrm{PtMe}_{2}$ (bipy) $>\mathrm{PtMe}_{2}$ (phen) $>\mathrm{PtCl}_{2}$ (bipy). Interestingly, $\mathrm{PdCl}{ }_{2}\left(\mathrm{PhCN}_{2}\right.$ and $\mathrm{Pd}\left(\mathrm{PPh}_{3}\right)_{4}$ had no activity at all. The yield of allyltin trichloride was not only dependent on the activity of the catalyst but also on the decomposition rate of the product in the presence of the catalyst. 3-Bromopropene gave $19 \%$ of allyltin tribromide when reacted with $\mathrm{SnBr}_{2}$. The other 3-haloalkenes did react but the resulting monoallylictin trihalides were not stable enough to produce significant yields. Reaction of both, benzyl chloride and chlorobenzene, led to catalyst decomposition. In addition, $\mathrm{SnCl}_{2}$ catalyzed formation of polybenzyl was observed in the case of benzyl chloride.

(c) 2003 Elsevier Ltd. All rights reserved.
\end{abstract}

\section{Introduction}

Monoalkyltin trihalides, $\mathrm{RSnX}_{3},(\mathrm{X}=\mathrm{Cl}, \mathrm{Br}, \mathrm{I} ; \mathrm{R}=\mathrm{alkyl})$ find application as precursors for PVC stabilizers, ${ }^{1}$ as catalysts for polyurethane production and as precursors for the deposition of $\mathrm{SnO}_{2}$-coatings on glass. ${ }^{2}$ They are produced industrially by a redistribution reaction, which is controlled by the stoichiometry of the reactants and which usually involves $\mathrm{X}=\mathrm{Cl}$ (Eq. (1)). ${ }^{3}$ For economic reasons, the $\mathrm{R}_{2} \mathrm{SnX}_{2}$ is converted in a subsequent step into the $\mathrm{R}_{4} \mathrm{Sn}$ starting material. Full conversion of $\mathrm{R}_{4} \mathrm{Sn}$ into 4 equiv. of $\mathrm{RSnCl}_{3}$ is only successful for allyl, ${ }^{4}$ vinyl ${ }^{5}$ and phenyltins ${ }^{6}$ or requires a catalyst in the case of alkyltins. ${ }^{7}$

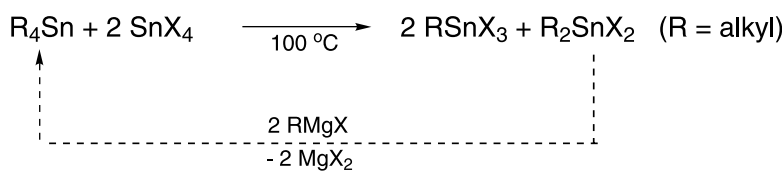

Another alternative, the direct reaction of alkyl halides with stannous halides (Eq. (2)), was studied extensively in the past but yields and selectivities are generally poor (for $\mathrm{X}=\mathrm{Cl}$ ) or the reaction involves the use of environmentally

Keywords: monoorganotin trihalides; allylic halides; direct reaction; platinum and palladium catalyzed; polybenzyl.

* Corresponding author. Tel.: +31-113-617225; fax: +31-113-612984; e-mail: berth-jan.deelman@atofina.com less desirable trialkylantimony catalysts. ${ }^{8 \mathrm{a}-\mathrm{c}}$ For example, octyltin trichloride is obtained in a low, $31 \%$, yield after a reaction time of $96 \mathrm{~h}$ at a temperature of $150^{\circ} \mathrm{C} .^{8 \mathrm{~b}}$

$\mathrm{RX}+\mathrm{SnX}_{2} \underset{(\mathrm{X}=\mathrm{Cl}, \mathrm{Br}, \mathrm{l})}{\stackrel{\mathrm{R}_{3}^{\prime} \mathrm{Sb}, 150^{\circ} \mathrm{C}}{\longrightarrow}} \mathrm{RSnX}_{3}$

In a relatively recent publication on the carbonyl allylation reaction it was shown that certain palladium complexes are able to catalyze the reaction of tin(II) halides with allyl halides. ${ }^{9}$ This reaction is believed to involve the in situ formation of solvated monoallyltin trichlorides and subsequent addition of the allyl-Sn bond across the carbonyl function of a range of aldehydes and ketones. The use of strongly coordinating solvents such as DMF, DMSO or THF renders this reaction unsuitable as a synthetic method for allyltin trihalides. To investigate the potential of several palladium and platinum complexes for the preparation of solvent free monoorganotin trichlorides, we decided to study their catalytic activity in the reaction of tin(II) halides with organic halides (Eq. (2)) in less strongly coordinating solvents like dichloromethane.

\section{Results and discussion}

3-Chloro-1-propene was reacted with tin(II) chloride in the presence of catalytic amounts of the complexes $\mathrm{MZ}_{2} \mathrm{~L}$ 
Table 1. Maximum yield of (allyl) $\mathrm{SnCl}_{3}$ for the reaction of $\mathrm{C}_{3} \mathrm{H}_{5} \mathrm{Cl}$ with $\mathrm{SnCl}_{2}$ in the presence of $5 \mathrm{~mol} \%$ of catalyst $\mathrm{MZ}_{2} \mathrm{~L}^{\mathrm{a}}$

\begin{tabular}{|c|c|c|c|c|c|c|c|c|}
\hline \multirow[t]{2}{*}{ Entry } & \multirow[t]{2}{*}{$\mathrm{L}-\mathrm{L}$} & \multirow[t]{2}{*}{$\mathrm{M}$} & \multirow[t]{2}{*}{$\mathrm{Z}$} & \multirow[t]{2}{*}{ Solvent } & \multicolumn{2}{|c|}{ Max. yield } & \multirow[t]{2}{*}{ Yield (\%) at $t=120 \mathrm{~h}$} & \multirow[t]{2}{*}{ Note } \\
\hline & & & & & $(\%)^{\mathrm{b}}$ & $t(\mathrm{~h})$ & & \\
\hline 1 & bipy & $\mathrm{Pt}$ & $\mathrm{Cl}$ & $\mathrm{CH}_{2} \mathrm{Cl}_{2}$ & 41 & 26 & 0 & \\
\hline 2 & bipy & $\mathrm{Pt}$ & $\mathrm{Me}$ & $\mathrm{CH}_{2} \mathrm{Cl}_{2}$ & 67 & 26 & 19 & $2 \% \mathrm{MeSnCl}_{3}$ \\
\hline 3 & phen & $\mathrm{Pt}$ & $\mathrm{Cl}$ & $\mathrm{CH}_{2} \mathrm{Cl}_{2}$ & 75 & 30 & 52 & \\
\hline 4 & phen & $\mathrm{Pt}$ & $\mathrm{Me}$ & $\mathrm{CH}_{2} \mathrm{Cl}_{2}$ & 62 & 30 & 14 & $2 \% \mathrm{MeSnCl}_{3}$ \\
\hline 5 & bipy & $\mathrm{Pd}$ & $\mathrm{Cl}$ & $\mathrm{CH}_{2} \mathrm{Cl}_{2}$ & 82 & 26 & 69 & \\
\hline 6 & bipy & $\mathrm{Pd}$ & $\mathrm{Me}$ & $\mathrm{CH}_{2} \mathrm{Cl}_{2}$ & 80 & 26 & 48 & $2 \% \mathrm{MeSnCl}_{3}$ \\
\hline 7 & phen & $\mathrm{Pd}$ & $\mathrm{Cl}$ & $\mathrm{CH}_{2} \mathrm{Cl}_{2}$ & 82 & 30 & 57 & \\
\hline 8 & phen & $\mathrm{Pd}$ & $\mathrm{Me}$ & $\mathrm{CH}_{2} \mathrm{Cl}_{2}$ & 83 & 30 & 64 & $4 \% \mathrm{MeSnCl}_{3}$ \\
\hline 9 & dppe & $\mathrm{Pt}$ & $\mathrm{Me}$ & $\mathrm{CH}_{2} \mathrm{Cl}_{2}$ & 13 & 53 & 8 & $4 \% \mathrm{MeSnCl}_{3}$ \\
\hline 10 & phen & $\mathrm{Pd}$ & $\mathrm{Me}$ & $\mathrm{CH}_{2} \mathrm{Cl}_{2}$ & 52 & 70 & 43 & $T=35^{\circ} \mathrm{C}$ \\
\hline 11 & phen & $\mathrm{Pd}$ & $\mathrm{Me}$ & $\mathrm{CH}_{2} \mathrm{Cl}_{2}$ & 71 & 17 & 35 & $T=65^{\circ} \mathrm{C}$ \\
\hline 12 & phen & $\mathrm{Pd}$ & $\mathrm{Me}$ & Toluene & 61 & 53 & 40 & \\
\hline 13 & phen & $\mathrm{Pd}$ & $\mathrm{Me}$ & $\mathrm{C}_{3} \mathrm{H}_{5} \mathrm{Cl}$ & 64 & 30 & 9 & \\
\hline 14 & phen & $\mathrm{Pd}$ & $\mathrm{Me}$ & THF & 66 & 46 & 39 & \\
\hline 15 & phen & $\mathrm{Pd}$ & $\mathrm{Me}$ & $\mathrm{C}_{6} \mathrm{H}_{4} \mathrm{Cl}_{2}-1,2$ & 74 & 46 & 22 & \\
\hline 16 & phen & $\mathrm{Pd}$ & $\mathrm{Me}$ & DMF & 0 & 24 & 0 & \\
\hline 17 & phen & $\mathrm{Pd}$ & $\mathrm{Me}$ & Acetone & 5 & 24 & 0 & \\
\hline
\end{tabular}

${ }^{a}$ Reaction conditions: $5 \mathrm{~mL}$ of solvent, $[\mathrm{RX}]=1.0 \mathrm{~mol} \mathrm{~L}^{-1},\left[\mathrm{SnX}_{2}\right]=0.2 \mathrm{~mol} \mathrm{~L}^{-1}, 5 \mathrm{~mol} \%$ of catalyst (relative to $\mathrm{SnCl}_{2}$ amount), $45^{\circ} \mathrm{C}$.

${ }^{\mathrm{b}}$ Percentage of $\mathrm{SnCl}_{2}$ converted into (allyl) $\mathrm{SnX}_{3}$, determined by $\mathrm{GC}$ analysis. phen=1,10-phenanthroline; bipy=2,2'-bipyridine. n.d.=not determined.

$(\mathrm{M}=\mathrm{Pt}, \mathrm{Pd} ; \mathrm{Z}=\mathrm{Cl}, \mathrm{Me} ; \mathrm{L}=$ chelating nitrogen or phosphorus ligand), as well as $\mathrm{PdCl}_{2}(\mathrm{PhCN})_{2}$ and $\mathrm{Pd}\left(\mathrm{PPh}_{3}\right)_{4}$. The progress of the reaction was monitored by treating reaction samples with an excess of EtMgBr (to convert the allyltin chlorides to the corresponding allyl ethyl tetraorganotin species) and subsequent analysis of these mixtures with GC (Table 1). The GC analyses were complicated by the fact that the sample pre-treatment procedure unfortunately afforded a redistribution mixture of $\mathrm{SnEt}_{4}$, (allyl) $\mathrm{SnEt}_{3}$ and $\mathrm{Allyl}_{2} \mathrm{SnEt}_{2}$ even for authentic samples of allyltin trichloride. However, the sum of the three integrated signals was found to correlate linearly with the amount of allyltin trichloride present. The reaction profile obtained by GC analysis was verified by ${ }^{1} \mathrm{H}$ NMR spectroscopy (Fig. 1) for the best catalyst (entry 8, Table 1) and was found to be in good agreement.

In general, the yields were significantly lower than quantitative as a result of the limited stability of the end product (vide infra). By comparing the maximum yields and the yield after $120 \mathrm{~h}$ and by inspection of Figure 1, this feature is immediately apparent. The data in Table 1 show that the reactions catalyzed by the palladium complexes give higher yields of allyltin trichloride than those catalyzed by the analogous platinum complexes (entries 1-8). Of the palladium complexes tested, $\mathrm{PdMe}_{2}$ (phen) gave the highest yield $(83 \%)$. Dppe complexes of the type $\mathrm{MZ}_{2}$ (dppe) $(\mathrm{M}=\mathrm{Pt}, \mathrm{Pd} ; \mathrm{Z}=\mathrm{Me}, \mathrm{Cl})$ were also tested but only $\mathrm{PtMe}_{2^{-}}$ (dppe) was found to display some activity. A maximum yield of $13 \%$ after $53 \mathrm{~h}$ (entry 9 ) was obtained. $\mathrm{Pd}\left(\mathrm{PPh}_{3}\right)_{4}$ and $\mathrm{PdCl}_{2}(\mathrm{PhCN})_{2}$, two typical catalysts for the carbonyl allylation reaction, ${ }^{9}$ were also tested but did not afford significant amounts of allyltin trichloride in $\mathrm{CH}_{2} \mathrm{Cl}_{2}$. The catalyst decomposed to Pd-black at an early stage of the reaction.

When dimethyl platinum or palladium complexes were used, the presence of small amounts $(2-4 \%)$ of methyltin trichloride $\left(\delta 1.69 ;{ }^{2} J_{\mathrm{HSn}}=99.6 \mathrm{~Hz}\right)$ was observed next to allyltin trichloride (Table 1). ${ }^{10}$ This indicates that part of

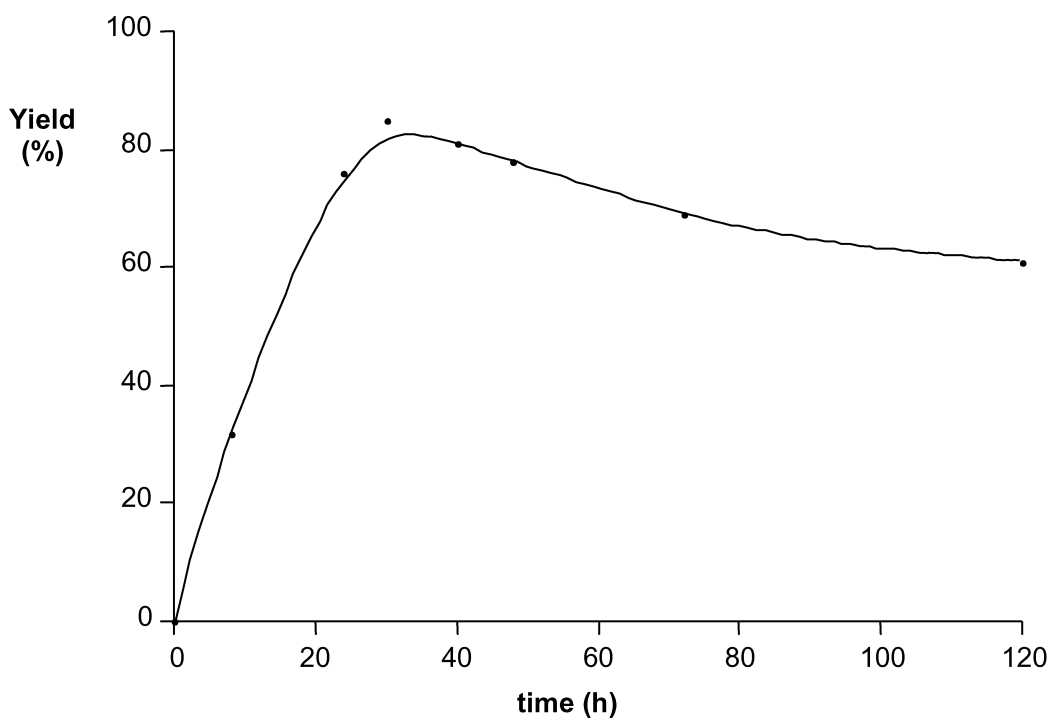

Figure 1. Plot of the yield of allyltin trichloride (\%) versus time (h) for the reaction of 3-chloropropene with $\mathrm{SnCl}_{2}$ catalyzed by $\mathrm{PdMe}_{2}\left(\right.$ phen) in $\mathrm{CH}_{2} \mathrm{Cl}_{2}$ at $45^{\circ} \mathrm{C}$ 
the methyl ligands of the catalyst were transferred to tin as well.

The experiment corresponding to entry 8 in Table 1 was also performed on preparative scale and stopped after $30 \mathrm{~h}$. At that time, just $10 \%$ of the initial amount of the poorly soluble $\mathrm{SnCl}_{2}$ could be recovered from the reaction mixture. Allyltin trichloride was isolated from the organic phase as a liquid in $84 \%$ yield. The ${ }^{1} \mathrm{H}$ NMR spectrum of the product revealed the presence of $5 \%$ of decomposition products. The isolated yield of allyltin trichloride is in good agreement with the yields determined by GC and ${ }^{1} \mathrm{H}$ NMR spectroscopic analysis of the reaction mixture.

After prolonged heating at the reaction temperature $\left(45^{\circ} \mathrm{C}\right)$, the decomposition of allyltin trichloride becomes apparent and is accompanied by the appearance of broad resonances at $\delta$ 0.6-2.6 and 5.3-5.9 in the ${ }^{1} \mathrm{H}$ NMR spectrum. The decomposition reaction was studied independently by monitoring solutions of pure allyltin trichloride over a period of time at 25 and $45^{\circ} \mathrm{C}$, respectively. The monitoring at $45^{\circ} \mathrm{C}$ was also carried out in the presence of catalyst (Fig. 2). From the data in Figure 2 it is obvious that the decomposition reaction is not only accelerated by the presence of catalyst but is even significant in the absence of catalyst. As both the platinum and the palladium catalyzed reactions are slow, we conclude that the yield of allyltin trichloride is determined by the relative rates of the catalyzed formation and the decomposition of allyltin trichloride. With the platinum catalysts, the decomposition reaction is faster than with the palladium catalysts, resulting in lower yields of product.

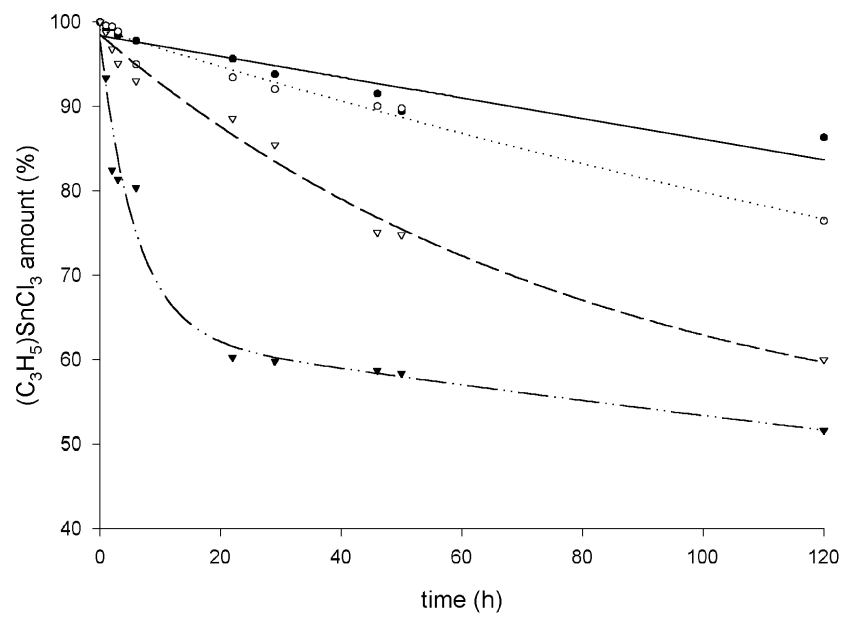

Figure 2. Plot of the (allyl) $\mathrm{SnCl}_{3}$ amount (\%) versus time (h) at $25^{\circ} \mathrm{C}(-)$, at $45^{\circ} \mathrm{C}(\cdots)$, at $45^{\circ} \mathrm{C}$ with $5 \mathrm{~mol} \%$ of $\mathrm{PdMe}_{2}$ (bipy) (-- ) and at $45^{\circ} \mathrm{C}$ with $5 \mathrm{~mol} \%$ of $\mathrm{PtMe}_{2}$ (bipy) (-..-.*).

The instability of allyl tin compounds has been discussed before and it was suggested that they decompose by cationic polymerization. ${ }^{4 \mathrm{~b}}$ To obtain more information on the decomposition products of allyltin trichloride, a sample was stored for several weeks in the dark at room temperature. After this period it had decomposed to a white solid and a sticky brown oil. The elemental analysis data of the white solid showed a $\mathrm{Sn} / \mathrm{Cl}$ molar ratio of 1:2.3 which is close to the theoretical 1:2 ratio for $\mathrm{SnCl}_{2}$, but the analogous data for the brown oil was more ambiguous. The presence of numerous resonances in the region $\delta 30-50$ and $120-140$ in the ${ }^{13} \mathrm{C}$ NMR spectrum as well as broad resonances in the ${ }^{1} \mathrm{H}$ NMR spectrum made it difficult to identify the nature of the products which most likely are polymeric in nature.

In our catalytic system, non-coordinating $\mathrm{CH}_{2} \mathrm{Cl}_{2}$ was used as solvent. In this way, allyltin trichloride can easily be obtained just by filtration of the reaction mixture followed by evaporation of all volatile components. This is in contrast to the system of Masuyama, ${ }^{11}$ which makes use of polar solvents, such as DMF, 1,3-dimethyl-2-imidazolidinone (DMI), DMSO, EtOH, DME or THF. These solvents coordinate to the Lewis acidic allyltin trichloride to give discrete 1:2 complexes (allyl) $\mathrm{SnCl}_{3}$ (solvent) ${ }_{2}$ (e.g. ${ }^{119} \mathrm{Sn}$ NMR: $\delta-488$ with DMF as solvent). These reactions are considerably faster which most likely relates to the difference in solubility of $\mathrm{SnCl}_{2}$ in the solvents used by Masuyama (soluble in DMF) and in the present study (insoluble in $\mathrm{CH}_{2} \mathrm{Cl}_{2}$ ).

When the reaction $\left(\mathrm{CH}_{2} \mathrm{Cl}_{2}\right.$ with $\mathrm{PdMe}$ (phen) as catalyst) was performed at 35 or $65^{\circ} \mathrm{C}$ instead of at $45^{\circ} \mathrm{C}$, the yields of allyltin trichloride were decreased (entry 10 and 11). At $35^{\circ} \mathrm{C}$, the highest yield was reached after a significantly longer reaction time $(70 \mathrm{~h})$. Entries $12-17$ of Table 1 show that with the other solvents tested, lower yields and faster decomposition of the formed allyltin trichloride occurred. Even the use of solvents such as THF and DMF, which are successfully applied in the carbonyl allylation of ketones and aldehydes, resulted in poor yields.

Next to 3-chloropropene, the reagents 3-chloro-2-methylpropene, 1-chloro-2-butene, 3-bromopropene, benzyl chloride and chlorobenzene were tested in the reaction with tin(II) halides with $\mathrm{PdMe}_{2}$ (phen) and $\mathrm{PtMe}_{2}$ (bipy) as catalyst.

3-Chloro-2-methylpropene and 1-chloro-2-butene were found to react with tin(II) chloride in $\mathrm{CH}_{2} \mathrm{Cl}_{2}$ at $45^{\circ} \mathrm{C}$. ${ }^{1} \mathrm{H}$ NMR spectroscopic analysis of the reaction mixtures after $24 \mathrm{~h}$ showed the presence of considerable amounts of decomposition products, whereas, resonances assigned to methallyl- or crotyltin trichloride were absent. ${ }^{4 \mathrm{~b}}$ Methallyltin trichloride and crotyltin trichloride are probably even less stable and decompose faster than allyltin trichloride under these conditions. This was confirmed by the presence of similar broad resonances in the ${ }^{1} \mathrm{H}$ NMR spectra as observed in the reaction of 3-chloropropene with tin(II) chloride.

3-Bromopropene reacted with $\mathrm{SnBr}_{2}$ in the presence of $\mathrm{PdMe}_{2}$ (phen) $(5 \mathrm{~mol} \%)$ in $\mathrm{CH}_{2} \mathrm{Cl}_{2}$ at $45^{\circ} \mathrm{C}$ to give allyltin tribromide in $19 \%$ yield after $48 \mathrm{~h}^{12,13}$ This yield is considerable lower than the yield of allyltin trichloride obtained in the reaction of allyl chloride with $\mathrm{SnCl}_{2}$ under comparable reaction conditions. Furthermore, significant formation of side-products was already observed after $24 \mathrm{~h}$, while for 3-chloropropene almost no side-product was formed at that time.

Reaction of benzyl chloride with $\mathrm{SnCl}_{2}$ led to the formation of considerable amounts of polybenzyl. ${ }^{14}$ In the ${ }^{1} \mathrm{H}$ NMR 


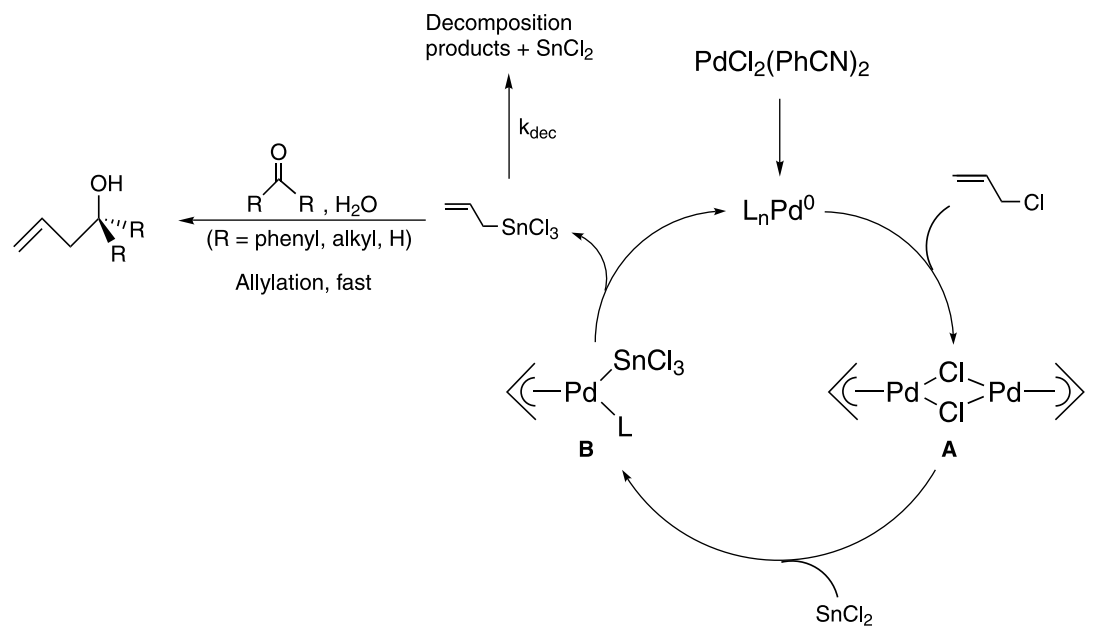

Scheme 1. Proposed mechanism for the palladium catalyzed formation of allyltin trichloride in the carbonyl allylation reaction with ketones and aldehydes with $\mathrm{L}=$ coordinating solvent or 3-chloropropene.

spectrum, broad resonances at $\delta 7.0$ and 3.8 were visible. The ${ }^{13} \mathrm{C}$ NMR chemical shift values corresponded with values reported in the literature. ${ }^{14}$ To investigate whether $\mathrm{PtMe}_{2}$ (bipy) is responsible for the polymerization reaction, an independent reaction without catalyst was carried out. Also in this case, formation of polybenzyl was significant suggesting that not the platinum complex, but $\mathrm{SnCl}_{2}$ itself acts as a catalyst for the polycondensation of benzyl chloride. Similar polymerization reactions of benzyl chloride catalyzed by other Lewis acids like $\mathrm{TlCl}_{3}$ and $\mathrm{AlCl}_{3}$ have been reported. ${ }^{14,15}$

For chlorobenzene, only decomposition of the catalyst into metal-black was observed ( $\mathrm{PdMe}_{2}$ (phen), $\mathrm{CH}_{2} \mathrm{Cl}_{2}, 45^{\circ} \mathrm{C}$ ).

\subsection{Mechanistic aspects}

Work by Masuyama and Kurosawa et al. on the palladiumcatalyzed carbonyl allylation of ketones and aldehydes by in situ generated allyltin trichloride suggested that this reaction most likely involves a $\mathrm{Pd}^{0} / \mathrm{Pd}^{\mathrm{II}}$ catalytic cycle. ${ }^{11,16}$ It was shown that the allyltin(IV) formation proceeds via the $\eta^{3}$ allyl(trichlorostannyl)palladium(II) intermediate B (Scheme 1). ${ }^{16}$ The formation of allyltin trichloride via reductive elimination is the rate-determining step and is followed by a fast allylation reaction of the carbonyl function of ketone or aldehyde to give the allylated product. ${ }^{9,16}$ Finally, it can be concluded that all through the reaction the actual concentration of allyltin trichloride will remain low. Most likely, a polar solvent is required for the latter step to be fast (vide supra).

In our system, allyltin trichloride is the end-product and does not subsequently react with a substrate to give a stable end-product. Consequently, the success of our system is highly dependent on the stability of allyltin trichloride and therefore, a small $k_{\mathrm{dec}}$ is required to obtain good yields.

By analogy and by taking into account that we are using palladium dichloride complexes with strongly coordinating bidentate ligands, the initial step in the catalysis might involve the formation of ionic $\left[\mathrm{Pd}\left(\eta^{3}\right.\right.$-allyl)(bipy)][Cl] (1), which is a known compound. ${ }^{17}$

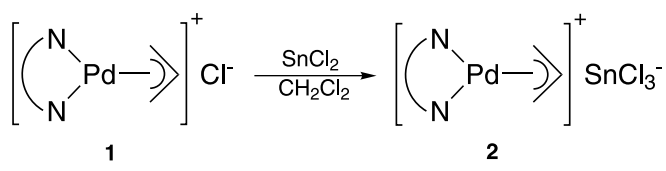

$\mathrm{N} \wedge \mathrm{N}=2,2^{\prime}$-bipyridine

Addition of 1 equiv. of $\mathrm{SnCl}_{2}$ to (1) in a separate reaction indeed resulted in quantitative formation of ionic $\left[\operatorname{Pd}\left(\eta^{3}-\right.\right.$ allyl)(bipy][$\left[\mathrm{SnCl}_{3}\right]$ (2) (Eq. (3)), which has an ${ }^{1} \mathrm{H}$ NMR spectrum similar to that reported for related $\left[\operatorname{Pd}\left(\eta^{3}-\right.\right.$ allyl)(bipy) $]\left[\mathrm{BF}_{4}\right] \cdot{ }^{18}$ In addition, the ${ }^{119} \mathrm{Sn}$ NMR chemical shift of $\delta-37.0$ is in agreement with the value found for a $\left[\mathrm{SnCl}_{3}\right]^{-}$anion like in $\left[\mathrm{PBu}_{3}^{t} \mathrm{H}\right]\left[\mathrm{SnCl}_{3}\right](\delta-30),\left[{ }^{\mathrm{n}} \mathrm{Bu}_{4} \mathrm{~N}\right]-$ $\left[\mathrm{SnCl}_{3}\right](\delta-42)$ and $\left[\mathrm{AsPh}_{4}\right]\left[\mathrm{SnCl}_{3}\right](\delta-51)$ (all measured in $\left.\mathrm{CH}_{2} \mathrm{Cl}_{2}\right) .{ }^{19} \mathrm{As}$ reported for $\left[\mathrm{Pd}\left(\eta^{3}\right.\right.$-allyl $\left.)\left(\mathrm{PPh}_{3}\right)_{2}\right]$ $\left[\mathrm{SnCl}_{3}\right],{ }^{20}$ also 2 did not reductively eliminate allyltin trichloride, neither in $\mathrm{CH}_{2} \mathrm{Cl}_{2}$ nor in a polar solvent as acetone- $d_{6}$, not even at the reaction temperature applied in the catalytic reaction $\left(45^{\circ} \mathrm{C}\right)$. However, when 2 was used as catalyst in the reaction of 3-chloropropene with $\mathrm{SnCl}_{2}$, activities similar to that of $\mathrm{PdCl}_{2}$ (bipy) were found.

Compound 2 was not reactive towards 3-chloropropene (excess in $\mathrm{CD}_{2} \mathrm{Cl}_{2}$ or acetone- $d_{6}, 25$ and $45^{\circ} \mathrm{C}$ ), whereas, 2 reacts with an excess of $\mathrm{SnCl}_{2}$ in $\mathrm{CD}_{2} \mathrm{Cl}_{2}$ to afford an unidentified allylic species but not allyltin trichloride. However, when the latter reaction was performed in acetone- $d_{6}$, slow formation of the butenylalkoxide $\mathrm{CH}_{2}=\mathrm{CH}-\mathrm{CH}_{2} \mathrm{C}\left(\mathrm{CD}_{3}\right)_{2} \mathrm{OSnCl}_{3}$ was observed (44\% after $0.5 \mathrm{~h}$ ) which is the result of direct reaction of acetone with allyltin trichloride (Scheme 2, see also Section 4). ${ }^{9,11}$ The ${ }^{1} \mathrm{H}$ NMR resonances perfectly matched those of an independently prepared sample of (allyl) $\mathrm{SnCl}_{3}$ recorded in acetone- $d_{6}{ }^{4 \mathrm{~b}}$ It can thus be concluded that reductive elimination of allyltin trichloride from $\mathbf{2}$ is possible but only leads to appreciable build-up of allyl chloride if its formation is competing effectively with decomposition. The<smiles>C=CC[Se][13CH2][Se-]C(C)=O</smiles>

Scheme 2. Reaction of (allyl) $\mathrm{SnCl}_{3}$ with acetone. 


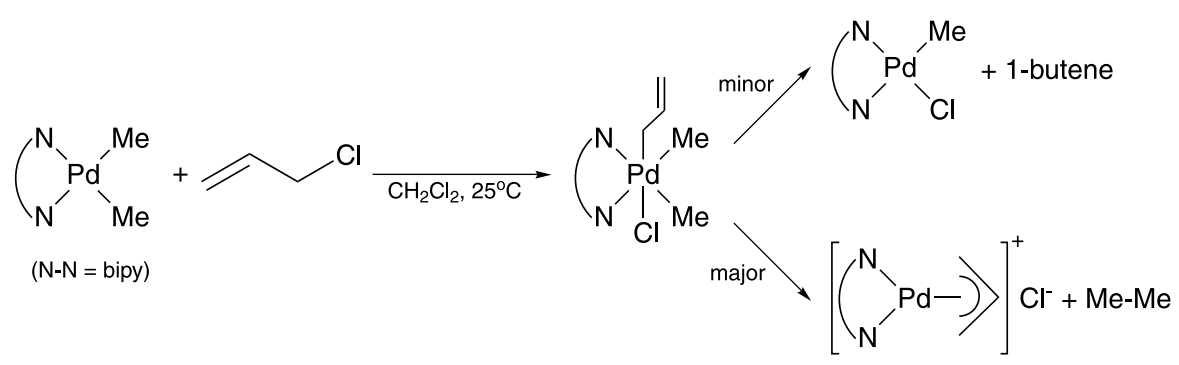

Scheme 3. Reaction of $\mathrm{PdMe}_{2}$ (bipy) with 3-chloropropene.

latter is only realized under catalytic conditions in the presence of sufficient amounts of both substrates. In addition, there is apparently also an effect of the excess $\mathrm{SnCl}_{2}$ on the reductive elimination step.

For the dimethyl palladium complexes $\mathrm{PdMe}_{2} \mathrm{~L}$, a different cycle could be operative. In order to obtain more insight in the reactivity of this pre-catalyst, independent reactions of $\mathrm{PdMe}_{2}$ (bipy) with both $\mathrm{SnCl}_{2}$ and 3-chloropropene were studied. When an excess of $\mathrm{SnCl}_{2}$ was added to a solution of $\mathrm{PdMe}_{2}$ (bipy) in $\mathrm{CH}_{2} \mathrm{Cl}_{2}$, the color of the solution turned orange instantaneously while deposition of palladium black became clearly visible. Analysis of the solution by ${ }^{1} \mathrm{H}$ NMR spectroscopy showed the absence of the initial palladium complex. Instead, the presence of the methylated product $\mathrm{Me}_{2} \mathrm{SnCl}_{2}\left(\delta 1.22 ;{ }^{1} J_{\mathrm{HSn}}=84 \mathrm{~Hz}\right)^{21}$ in the reaction mixture was observed. This indicates that the methyl ligands of the initial palladium complex have been transferred from palladium(II) to tin(II). Apparently, $\mathrm{SnCl}_{2}$ has acted as reducing agent in the reaction with $\mathrm{PdMe}_{2}$ (bipy) (Eq. (4)).

$$
\left(\underset{N^{\prime}}{\mathrm{Pd}^{\prime}}{ }_{\mathrm{Me}}^{\mathrm{Me}}+\underset{\text { (excess) }}{\mathrm{SnCl}_{2}} \stackrel{ }{\mathrm{CH}_{2} \mathrm{Cl}_{2}, 25^{\circ} \mathrm{C}} \text { Pd-black }+\mathrm{Me}_{2} \mathrm{SnCl}_{2}\right.
$$

$\left(\mathrm{N}^{\wedge} \mathrm{N}=2,2\right.$-bipyridine $)$

The reaction of 3-chloropropene (excess) with $\mathrm{PdMe}_{2}$ (bipy) afforded in ca. ten minutes $\left[\mathrm{Pd}\left(\eta^{3}\right.\right.$-allyl)(bipy)][Cl] ${ }^{17}(\mathbf{1})$ along with traces of $\mathrm{PdMe}(\mathrm{Cl})$ (bipy) (Scheme 3$).{ }^{18}$ This result is in line with the observations made by Canty et al. for the reaction of allyl bromide with $\mathrm{PdMe}_{2}$ (bipy). ${ }^{18}$

To study the extent of competition of the reactions of $\mathrm{PdMe}_{2}$ (bipy) with either $\mathrm{SnCl}_{2}$ (Eq. (4)) or 3-chloropropene (Scheme 3), respectively, $\mathrm{SnCl}_{2}$ and 3-chloropropene (both 1 equiv.) were added to a solution of $\mathrm{PdMe}_{2}$ (bipy) in $\mathrm{CD}_{2} \mathrm{Cl}_{2}$. After ten minutes at room temperature, two singlet Me resonances without tin satellites were visible in the ${ }^{1} \mathrm{H}$ NMR spectrum ( $\delta 0.90$ and 1.71). Analysis of the solution by ${ }^{1} \mathrm{H}$ NMR after $24 \mathrm{~h}$ showed the presence of $\mathrm{Me}_{2} \mathrm{SnCl}_{2}$, $\left[\operatorname{Pd}\left(\eta^{3}\right.\right.$-allyl)(bipy] $\left[\mathrm{SnCl}_{3}\right]$ and several unidentified singlet resonances $(\delta 0.66,0.86$ and 1.67$)$ which may originate from ethane and butene formation. The formation of $\mathrm{Me}_{2} \mathrm{SnCl}_{2}$ and $\left[\mathrm{Pd}\left(\eta^{3}\right.\right.$-allyl)(bipy] $\left[\mathrm{SnCl}_{3}\right]$ would suggest a $\mathrm{Pd}^{0} / \mathrm{Pd}^{\mathrm{II}}$ catalytic cycle similar to that of $\mathrm{PdCl}_{2}$ (bipy). However, under catalytic conditions, no $\mathrm{Me}_{2} \mathrm{SnCl}_{2}$ but $\mathrm{MeSnCl}_{3}(2-4 \%)$ was detected. Formation of $\mathrm{MeSnCl}_{3}$ may well be the result of reductive elimination from $\left[\mathrm{Pd}(\mathrm{Me})(\right.$ bipy $]\left[\mathrm{SnCl}_{3}\right]$ (minor route in Scheme 3 followed by $\mathrm{SnCl}_{2}$ insertion). $\left[\mathrm{Pd}\left(\eta^{3}\right.\right.$-allyl)(bipy] $\left[\mathrm{SnCl}_{3}\right]$ may well be resulting from $\mathrm{SnCl}_{2}$ insertion in the $\mathrm{Pd}-\mathrm{Cl}$ bond of $\left[\operatorname{PdCl}\left(\eta^{3}\right.\right.$-allyl)(bipy] but is part of both catalyst activation mechanisms. Even if a $\mathrm{Pd}^{\mathrm{IV}}$ species is involved, once the methyl groups have been transferred, the catalyst enters the same cycle as was proposed for the palladium chloride complexes (Scheme 1).

Next to the palladium complexes the analogous platinum complexes were investigated and subjected to stoichiometric reactions with the substrate. The platinum dichloride complex $\mathrm{PtCl}_{2}$ (bipy) was found not to react with a four-fold excess of 3-chloropropene. On the other hand, when a fourfold excess of $\mathrm{SnCl}_{2}$ was added, the color of the reaction mixture changed from yellow to bright orange. The reaction mixture was stirred for $24 \mathrm{~h}$ at $45^{\circ} \mathrm{C}$, after which a orange solid was isolated from the solution. A ${ }^{1} \mathrm{H}$ NMR spectrum recorded in acetone- $d_{6}$ showed no resonances of the initial platinum compound. The resonances in the aromatic region pointed towards a complex mixture of several newlyformed bipy complexes that might include species like $\mathrm{PtCl}\left(\mathrm{SnCl}_{3}\right)$ (bipy) and $\mathrm{Pt}\left(\mathrm{SnCl}_{3}\right)_{2}$ (bipy). Attempts to identify these complexes were without any success, due to the overlap of several resonances, preventing further mechanistic investigations.

The platinum analogue $\mathrm{PtMe}_{2}$ (bipy), was reacted with $\mathrm{SnCl}_{2}$ and 3-chloropropene. When an excess of $\mathrm{SnCl}_{2}$ was added to a solution of $\mathrm{PtMe}_{2}$ (bipy) in $\mathrm{CH}_{2} \mathrm{Cl}_{2}$, no reaction was observed within ten minutes. A sample of the reaction mixture analyzed by ${ }^{1} \mathrm{H}$ NMR spectroscopy, showed $\mathrm{PtMe}_{2}$ (bipy) ${ }^{22}$ to be the only compound present. On the other hand, $\mathrm{PtMe}_{2}$ (bipy) reacted completely with 3-chloropropene within one minute and resulted in quantitative formation of the expected trans-oxidative addition product $\left[\mathrm{PtMe}_{2}(\right.$ allyl $)(\mathrm{Cl})($ bipy $\left.)\right] .^{23}$

These results suggest that an oxidative addition reaction of 3-chloropropene with $\mathrm{PtMe}_{2}(\mathrm{~N} \wedge \mathrm{N})(\mathrm{N} \wedge \mathrm{N}=$ bipy, phen $)$

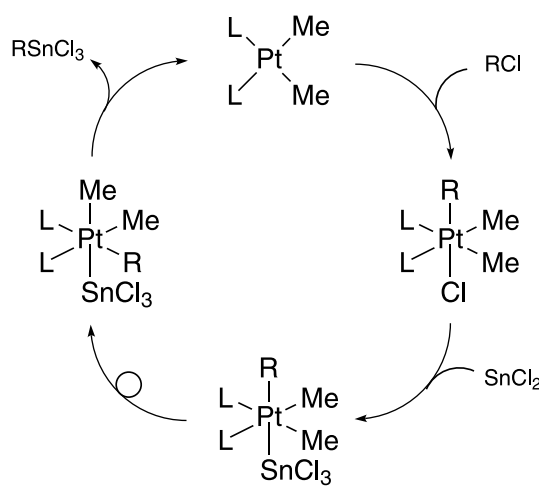

Scheme 4. Postulated catalytic cycle for the $\mathrm{PtMe}_{2} \mathrm{~L}$ catalyzed formation of allyltin trichloride $\left(\mathrm{R}=\mathrm{C}_{3} \mathrm{H}_{5} ; \mathrm{N} \wedge \mathrm{N}=\right.$ bipy, phen $)$. 
takes place at first (Scheme 4). Previously, it was demonstrated that the insertion of tin(II) chloride into the platinum-chloride bond of $\left[\mathrm{PtMe}_{2}(\right.$ allyl $)(\mathrm{Cl})($ bipy $\left.)\right]$ is also fast and results in the formation of $\left[\mathrm{PtMe}_{2}(\right.$ allyl $)\left(\mathrm{SnCl}_{3}\right)$ (bipy)] (3). ${ }^{24}$ Before reductive elimination of allyltin trichloride can take place, the octahedral complex has to rearrange to position the allyl ligand cis to the $\mathrm{SnCl}_{3}$ ligand. ${ }^{25}$ This trans to cis isomerization takes place via a five-coordinate intermediate ${ }^{26}$ by dissociation of a weakly coordinating ligand such as $\mathrm{SnCl}_{3} .{ }^{27} \mathrm{Next}$, reductive elimination of allyltin trichloride results in the re-formation of the starting complex $\mathrm{PtMe}_{2} \mathrm{~L}$. To investigate whether complex 3 does indeed undergo reductive formation of $\mathrm{Sn}-$ $\mathrm{C}$ bonds, a solution of $\mathbf{3}$ in acetone- $d_{6}$ was examined by ${ }^{1} \mathrm{H}$ NMR spectroscopy. While complex 3 was stable for 2 days at $25^{\circ} \mathrm{C}$, at $60^{\circ} \mathrm{C} 3$ gave in $12 \mathrm{~h}$ almost quantitative formation of butenylalkoxide (vide supra) that results from consecutive reaction of (allyl) $\mathrm{SnCl}_{3}$ with acetone (Scheme 2). These results confirm that $\mathbf{3}$ can undergo reductive elimination to afford allyltin trichloride. While the oxidative addition of 3-chloropropene and the insertion of $\mathrm{SnCl}_{2}$ are fast, reductive elimination step is slow and probably the rate determining step in the catalytic cycle.

In the postulated catalytic cycle, not only an allyl substituent, but also a Me substituent is orientated in the cis position to the $\mathrm{SnCl}_{3}$ ligand. Consequently, formation of $\mathrm{MeSnCl}_{3}$ that is observed in the catalytic reaction, can be explained by this mechanism.

\section{Conclusion}

Despite its thermal instability, allyltin trichloride could be prepared under mild conditions by the direct reaction of 3-chloropropene and $\mathrm{SnCl}_{2}$ catalyzed by platinum and palladium 2,2'-bipyridine and 1,10-phenanthroline complexes. In general, the palladium catalysts give higher yields of allyltin trichloride than the analogous platinum complexes. This effect is ascribed to a lower decomposition rate of the product when palladium catalysts are used. Unfortunately, this approach fails for other organic halides. Some brief mechanistic studies show that most likely a $\mathrm{Pd}^{0} / \mathrm{Pd}^{\mathrm{II}}$ catalytic cycle is operative for the $\mathrm{PdCl}_{2} \mathrm{~L}$ complexes. The $\mathrm{PtMe}_{2} \mathrm{~L}$ complexes follow a $\mathrm{Pt}^{\mathrm{II}} / \mathrm{Pt}^{\mathrm{IV}}$ cycle, while the mechanism involved for $\mathrm{PtCl}_{2} \mathrm{~L}$ and $\mathrm{PdMe}_{2} \mathrm{~L}$ remains less well defined.

\section{Experimental}

\subsection{General procedure}

All reactions were performed under a dry nitrogen atmosphere using standard Schlenk techniques. $\mathrm{PtMe}_{2}-$ (bipy), ${ }^{28} \mathrm{PtCl}_{2}$ (bipy), ${ }^{29} \mathrm{PtMe}_{2}$ (dppe), ${ }^{30} \mathrm{PtCl}_{2}$ (dppe), ${ }^{31}$ $\mathrm{PtCl}_{2}$ (phen), ${ }^{32} \mathrm{PtMe}_{2}$ (phen), ${ }^{22} \mathrm{PdMe}_{2}$ (bipy), ${ }^{33} \mathrm{PdCl}_{2}-$ (bipy), ${ }^{34} \mathrm{PdMe}_{2}$ (dppe), ${ }^{35} \mathrm{PdCl}_{2}$ (dppe), ${ }^{36} \mathrm{PdMe}_{2}$ (phen), ${ }^{33}$ $\mathrm{PdCl}_{2}$ (phen), ${ }^{34} \mathrm{PdCl}_{2}(\mathrm{PhCN})_{2},{ }^{37} \mathrm{Pd}\left(\mathrm{PPh}_{3}\right)_{4},{ }^{38} \mathrm{PdCl}($ allyl $)-$ (bipy) ${ }^{17}$ and allyltin trichloride ${ }^{39}$ were prepared according to literature procedures. Dichloromethane was distilled from $\mathrm{CaH}_{2}$; all organic halides were distilled and stored on molsieves $3 \AA$. Commercially available anhydrous $\mathrm{SnCl}_{2}$ and $\mathrm{SnBr}_{2}$ were stored under a nitrogen atmosphere; $\mathrm{CDCl}_{3}$ was stored under a nitrogen atmosphere on molsieves $3 \AA$. Toluene was used as internal standard to determine the yields by ${ }^{1} \mathrm{H}$ NMR spectroscopy $(100 \mu \mathrm{L}$ of toluene in $10 \mathrm{~mL}$ of $\left.\mathrm{CDCl}_{3}\right) .{ }^{1} \mathrm{H},{ }^{13} \mathrm{C}\left\{{ }^{1} \mathrm{H}\right\}$ and ${ }^{119} \mathrm{Sn}\left\{{ }^{1} \mathrm{H}\right\}$ NMR spectra were recorded on a Bruker AC $200 \mathrm{MHz}$ or on Varian Inova $300 \mathrm{MHz}$ NMR spectrometer with $\mathrm{Me}_{4} \mathrm{Si}\left({ }^{1} \mathrm{H}\right.$ and $\left.{ }^{13} \mathrm{C}\right)$ and $\mathrm{Me}_{4} \mathrm{Sn}\left({ }^{119} \mathrm{Sn}\right)$ as external references. GC analysis were carried out on a Perkin-Elmer instrument consisting of an Autosystem XL GC. GC-MS analysis were carried out on a Perkin-Elmer instrument consisting of an Autosystem XL GC and a Turbomass MS. Elemental analysis were carried out by H. Kolbe, Mikroanalytisches Laboratorium, Mülheim an der Ruhr, Germany.

4.1.1. Typical procedure for the reaction of organic halide with $\mathrm{SnX}_{2}(\mathrm{X}=\mathrm{Cl}, \mathrm{Br})$ catalyzed by $5 \mathrm{~mol} \%$ of catalyst. To anhydrous tin(II) halide (1 mmol) in a Schlenk flask, $5 \mathrm{~mL}$ of dry solvent was added. After addition of the organic halide $(5 \mathrm{mmol})$, internal standard $n$-tridecane $(100 \mu \mathrm{L})$ and the catalyst $(0.05 \mathrm{mmol}, 5 \mathrm{~mol} \%)$, the reaction mixture was heated to the desired temperature. A $50 \mu \mathrm{L}$ sample was taken from the reaction mixture at regular intervals and reacted with $1.0 \mathrm{M} \mathrm{EtMgBr}$ in $\mathrm{Et}_{2} \mathrm{O}$ $(3 \mathrm{~mL})$. The sample was quenched with $5 \mathrm{~mL}$ of water and the upper $\mathrm{Et}_{2} \mathrm{O}$ layer was analyzed by GC and GC-MS. The yield of allyltin trichloride was calculated from the sum of the integrals of $\mathrm{SnEt}_{4}, \mathrm{Sn}\left(\mathrm{C}_{3} \mathrm{H}_{5}\right) \mathrm{Et}_{3}$ and $\mathrm{Sn}\left(\mathrm{C}_{3} \mathrm{H}_{5}\right)_{2} \mathrm{Et}_{2}$ signals and calibrated to the internal standard ( $n$-tridecane). The total area of the three signals was found to correlate well with the amount of allyltin trichloride.

Analysis of the reaction mixture by NMR spectroscopy was carried out as follows: after cooling of the reaction mixture to room temperature, a $500 \mu \mathrm{L}$ sample was taken and evaporated till dryness. Next, $600 \mu \mathrm{L}$ of $\mathrm{CDCl}_{3}$ with internal toluene standard was added to the residue. The sample was analyzed by ${ }^{1} \mathrm{H},{ }^{13} \mathrm{C}$ and ${ }^{119} \mathrm{Sn}$ NMR spectroscopy. NMR data of allyltin trichloride, ${ }^{1} \mathrm{H}$ NMR $\left(\mathrm{CDCl}_{3}, 25^{\circ} \mathrm{C}\right): \delta 3.14\left(\mathrm{~d}, 2 \mathrm{H}, J_{\mathrm{HSn}}=119 \mathrm{~Hz}, \mathrm{CH}_{2}-\mathrm{Sn}\right)$, 5.19-5.66 (m, 2H, $\left.\mathrm{CH}_{2}\right), 5.75-6.14(\mathrm{~m}, 1 \mathrm{H}, \mathrm{CH}) .{ }^{13} \mathrm{C} \mathrm{NMR}$ $\left(\mathrm{CDCl}_{3}, \quad 25^{\circ} \mathrm{C}\right): \quad \delta 36.3 \quad\left({ }^{1} J_{\mathrm{CSn}}=314.9 \mathrm{~Hz}\right), \quad 122.0$ $\left({ }^{2} J_{\mathrm{CSn}}=72.3 \mathrm{~Hz}\right), 127.2 \quad\left({ }^{3} J_{\mathrm{CSn}}=65.4 \mathrm{~Hz}\right) .{ }^{119} \mathrm{Sn}$ NMR $\left(\mathrm{CDCl}_{3}, 25^{\circ} \mathrm{C}\right): \delta-29.0$. GC-MS m/e (rel. intensity): 236 $\left(3, \mathrm{M}^{+}\right), 207$ (82), 179 (98), 149 (100), 58 (121); SnEt $_{4} .219$ (12, $\mathrm{M}^{+}-\mathrm{C}_{2} \mathrm{H}_{5}$ ), 207 (45), 179 (50), 149 (100), 121 (47); $\mathrm{Sn}\left(\mathrm{C}_{3} \mathrm{H}_{5}\right) \mathrm{Et}_{3} .231\left(12, \mathrm{M}^{+}-\mathrm{C}_{2} \mathrm{H}_{5}\right), 219$ (35), 161 (38), 149 (100), 121 (33); $\mathrm{Sn}\left(\mathrm{C}_{3} \mathrm{H}_{5}\right)_{2} \mathrm{Et}_{2}$.

NMR data of allyltin tribromide, ${ }^{1} \mathrm{H} \mathrm{NMR}\left(\mathrm{CDCl}_{3}, 25^{\circ} \mathrm{C}\right): \delta$ $3.23\left(\mathrm{~d}, 2 \mathrm{H}, J_{\mathrm{HSn}}=108 \mathrm{~Hz}, \mathrm{CH}_{2}-\mathrm{Sn}\right), 5.28-5.47(\mathrm{~m}, 2 \mathrm{H}$, $\left.\mathrm{CH}_{2}\right), 5.74-6.14(\mathrm{~m}, 1 \mathrm{H}, \mathrm{CH})$. The concentration of allyltin tribromide was too low to obtain satisfactorily ${ }^{13} \mathrm{C}$ and ${ }^{119} \mathrm{Sn}$ NMR spectra.

The reaction on a preparative scale was carried out as described above using $\mathrm{SnCl}_{2}(0.95 \mathrm{~g}, 5 \mathrm{mmol})$, 3-chloropropene $(1.9 \mathrm{~g}, 25 \mathrm{mmol}), \mathrm{PdMe}_{2}$ (phen) (79 $\mathrm{mg}$, $0.25 \mathrm{mmol}, 0.5 \mathrm{~mol} \%)$ and $\mathrm{CH}_{2} \mathrm{Cl}_{2}(25 \mathrm{~mL})$. After the reaction mixture was heated for $30 \mathrm{~h}$ at $45^{\circ} \mathrm{C}$, it was cooled to room temperature and filtered. Evaporation of the solvent from the residue in vacuo resulted in $1.18 \mathrm{~g}$ of a slightly yellow colored oil. The oil was analyzed by ${ }^{1} \mathrm{H}$ NMR and 
found to contain allyltin trichloride in $95 \%$ purity along with some decomposition product (see text), corresponding to an $84 \%$ yield.

\subsubsection{Decomposition studies of allyltin trichloride.} Without solvent. A sample of freshly prepared (allyl) $\mathrm{SnCl}_{3}$ $(3.4 \mathrm{~g})$ was stored for several weeks in the dark at room temperature. $\mathrm{CH}_{2} \mathrm{Cl}_{2}(10 \mathrm{~mL})$ was added and the suspension was filtrated. The white solid was washed two times with $\mathrm{CH}_{2} \mathrm{Cl}_{2}(5 \mathrm{~mL})$ and dried in vacuo $(0.25 \mathrm{~g})$. Elem. anal. Found: $\mathrm{Sn}, 47.07 ; \mathrm{Cl}, 31.43 \%$. The volatiles from the filtrate were removed in vacuo to give a brown sticky material $(3.0$ g). Elem. anal. Found: C, 16.08; H, 2.38; Sn, 40.02; Cl, $36.03 \% .{ }^{1} \mathrm{H} \mathrm{NMR}\left(\mathrm{CDCl}_{3}, 25^{\circ} \mathrm{C}\right): \delta 0.6-2(\mathrm{br}, 3 \mathrm{H}), 2.2-2.6$ (br, 9H), 5.3-5.6 (m, 2H), 5.7-5.9 (m, 1H). ${ }^{13} \mathrm{C}$ NMR $\left(\mathrm{CDCl}_{3}, 25^{\circ} \mathrm{C}\right): \delta 33.5,39.8\left(J_{\mathrm{CSn}}=69.8 \mathrm{~Hz}\right),{ }^{40} 43.4,123.5$, $132.9 \mathrm{ppm}$

In $\mathrm{CH}_{2} \mathrm{Cl}_{2}$. Four aliquots of freshly prepared (allyl) $\mathrm{SnCl}_{3}$ (200 mg, $0.75 \mathrm{mmol}$ ) in $5 \mathrm{~mL}$ of $\mathrm{CH}_{2} \mathrm{Cl}_{2}$ with $n$-tridecane $(100 \mu \mathrm{L})$ were prepared. To the first and the second, $\mathrm{PtMe}_{2}$ (bipy) (38 mg, $0.1 \mathrm{mmol}$ ) and $\mathrm{PdMe}_{2}$ (bipy) (29 mg, $0.1 \mathrm{mmol}$ ), respectively, were added. These two solutions together with a solution that did not contain the metal complex, were stored at $45^{\circ} \mathrm{C}$. The fourth solution was stored at $25^{\circ} \mathrm{C}$. For the analysis of the reaction mixtures a $50 \mu \mathrm{L}$ sample was taken and was reacted with $1.0 \mathrm{M}$ EtMgBr in $\mathrm{Et}_{2} \mathrm{O}(3 \mathrm{~mL})$. The sample was quenched with $5 \mathrm{~mL}$ of water and the upper $\mathrm{Et}_{2} \mathrm{O}$ layer was analyzed by GC.

4.1.3. Synthesis of $\left[\operatorname{Pd}\left(\eta^{3}\right.\right.$-allyl)(bipy $]\left[\mathrm{SnCl}_{3}\right]$ (2). $\mathrm{PdCl}$ (allyl)(bipy) (130 mg, $0.39 \mathrm{mmol})$ was suspended in $10 \mathrm{~mL}$ of $\mathrm{CH}_{2} \mathrm{Cl}_{2}$. $\mathrm{SnCl}_{2}(73 \mathrm{mg}, 0.39 \mathrm{mmol})$ was added to the suspension and the reaction mixture was stirred for 3 days at room temperature. Filtration of the reaction mixture resulted in the isolation of a light yellow powder $(133 \mathrm{mg}$, $65 \%$ yield). Mp $182^{\circ} \mathrm{C}$ (dec). ${ }^{1} \mathrm{H}$ NMR $\left(\mathrm{CD}_{2} \mathrm{Cl}_{2},-25^{\circ} \mathrm{C}\right): \delta$ $3.56\left(\mathrm{~d}, 2 \mathrm{H},{ }^{3} \mathrm{~J}_{\mathrm{HH}}=12.6 \mathrm{~Hz}, \mathrm{Pd}-\mathrm{CH}_{2}\right), 4.28(\mathrm{~d}, 2 \mathrm{H}$, ${ }^{3} J_{\mathrm{HH}}=6.9 \mathrm{~Hz}$, allylic $\left.\mathrm{CH}_{2}\right), 6.09\left(\mathrm{~m}, 1 \mathrm{H},{ }^{3} J_{\mathrm{HH}}=9.0 \mathrm{~Hz}\right)$, $7.71\left(\mathrm{t}, 2 \mathrm{H},{ }^{3} J_{\mathrm{HH}}=7.2 \mathrm{~Hz}\right.$, bipy), $8.28\left(\mathrm{t}, 2 \mathrm{H},{ }^{3} \mathrm{~J}_{\mathrm{HH}}=8.7 \mathrm{~Hz}\right.$, bipy), 8.42 (d, $2 \mathrm{H},{ }^{3} J_{\mathrm{HH}}=8.1 \mathrm{~Hz}$, bipy), $8.83(\mathrm{~d}, 2 \mathrm{H}$, ${ }^{3} J_{\mathrm{HH}}=4.8 \mathrm{~Hz}$, bipy). ${ }^{119} \mathrm{Sn}\left(\mathrm{CD}_{2} \mathrm{Cl}_{2}, 25^{\circ} \mathrm{C}\right): \delta-37.0$. Anal. calcd. for $\mathrm{C}_{13} \mathrm{H}_{13} \mathrm{Cl}_{3} \mathrm{~N}_{2} \mathrm{PdSn}: \mathrm{C}, 29.53 ; \mathrm{H}, 2.48 ; \mathrm{N}, 5.30 ; \mathrm{Cl}$, 20.12. Found: C, 29.44; H, 2.40; N, 5.21; Cl, 20.16.

4.1.4. Reaction of $\left[\operatorname{Pd}\left(\eta^{3}\right.\right.$-allyl)(bipy] $\left[\mathrm{SnCl}_{3}\right]$ (2) with 3chloropropene or $\mathbf{S n C l}_{2}$. A solution of $\mathbf{2}(10 \mathrm{mg}$, $0.02 \mathrm{mmol}$ ) in $1 \mathrm{~mL}$ of $\mathrm{CD}_{2} \mathrm{Cl}_{2}$ or acetone- $d_{6}$ was transferred in a NMR tube. Next, $\mathrm{SnCl}_{2}(15 \mathrm{mg}$, $0.08 \mathrm{mmol})$ or 3 -chloropropene $(7 \mu \mathrm{L}, 0.08 \mathrm{mmol})$ was added. After the tube was sealed, it was stored at room temperature or it was placed in an oil bath of $45^{\circ} \mathrm{C}$. The solution was analysed by ${ }^{1} \mathrm{H}$ NMR spectroscopy at regular intervals. ${ }^{1} \mathrm{H}$ NMR of the reaction with $\mathrm{SnCl}_{2}$ in $\mathrm{CD}_{2} \mathrm{Cl}_{2}$ $\left(25^{\circ} \mathrm{C}\right): \delta 3.40\left(\mathrm{~d}, 2 \mathrm{H}, \mathrm{CH}_{2},{ }^{3} \mathrm{~J}_{\mathrm{HH}}=13.2 \mathrm{~Hz}\right), 5.10(\mathrm{~d}, 2 \mathrm{H}$, $\left.\mathrm{CH}_{2},{ }^{3} \mathrm{~J}_{\mathrm{HH}}=7.4 \mathrm{~Hz}\right), 5.23-5.44(\mathrm{~m}, 1 \mathrm{H}, \mathrm{CH}), 7.72(\mathrm{t}, 2 \mathrm{H}$, bipy, $\left.{ }^{3} J_{\mathrm{HH}}=13.2 \mathrm{~Hz}\right), 8.27\left(\mathrm{t}, 2 \mathrm{H}\right.$, bipy, $\left.{ }^{3} J_{\mathrm{HH}}=8.3 \mathrm{~Hz}\right), 8.35$ (d, 2H, bipy, $\left.{ }^{3} J_{\mathrm{HH}}=7.4 \mathrm{~Hz}\right), \quad 8.82(\mathrm{~d}, \quad 2 \mathrm{H}, \quad$ bipy, $\left.{ }^{3} J_{\mathrm{HH}}=6.4 \mathrm{~Hz}\right) .{ }^{1} \mathrm{H}$ NMR of the reaction with $\mathrm{SnCl}_{2}$ in acetone- $d_{6}\left(25^{\circ} \mathrm{C}\right): \delta 2.19\left(\mathrm{~d}, 2 \mathrm{H}, \mathrm{CH}_{2},{ }^{3} J_{\mathrm{HH}}=5.0 \mathrm{~Hz}\right)$, 4.96-5.10 (m, 2H, $\left.\mathrm{CH}_{2}\right), 5.81-6.02(\mathrm{~m}, 1 \mathrm{H}, \mathrm{CH})$ for $\mathrm{CH}_{2}=\mathrm{CH}-\mathrm{CH}_{2} \mathrm{C}\left(\mathrm{CD}_{3}\right)_{2} \mathrm{OSnCl}_{3}$ and $\delta 8.09\left(\mathrm{t},{ }^{3} J_{\mathrm{HH}}=\right.$
$5.4 \mathrm{~Hz}$, bipy 1), $8.25\left(\mathrm{t},{ }^{3} J_{\mathrm{HH}}=6.9 \mathrm{~Hz}\right.$, bipy 2$), 8.56(\mathrm{t}$, ${ }^{3} J_{\mathrm{HH}}=8.1 \mathrm{~Hz}$, bipy 1$), 8.70\left(\mathrm{~d},{ }^{3} J_{\mathrm{HH}}=8.1 \mathrm{~Hz}\right.$, bipy 2$), 8.86$ $\left(\mathrm{d},{ }^{3} J_{\mathrm{HH}}=8.1 \mathrm{~Hz}\right.$, bipy 1), $9.04\left(\mathrm{~d},{ }^{3} J_{\mathrm{HH}}=8.1 \mathrm{~Hz}\right.$, bipy 2$)$, $9.39\left(\mathrm{~d},{ }^{3} J_{\mathrm{HH}}=5.4 \mathrm{~Hz}\right.$, bipy 1$), 9.57\left(\mathrm{~d},{ }^{3} J_{\mathrm{HH}}=5.4 \mathrm{~Hz}\right.$, bipy $)$ for the bipy resonances. An independently prepared sample of (allyl) $\mathrm{SnCl}_{3}$ in acetone- $d_{6}$ showed the same characteristic resonances for $\mathrm{CH}_{2}=\mathrm{CH}-\mathrm{CH}_{2} \mathrm{C}\left(\mathrm{CD}_{3}\right)_{2} \mathrm{OSnCl}_{3}$ in the ${ }^{1} \mathrm{H}$ NMR spectrum. ${ }^{4 b}$

4.1.5. Reaction of (allyl)SnCl 3 with acetone. Allyltin trichloride $(0.5 \mathrm{~g}, 1.8 \mathrm{mmol})$ was added dropwise to acetone $(5 \mathrm{~mL})$ at room temperature. After ten minutes, $\mathrm{H}_{2} \mathrm{O}(2 \mathrm{~mL})$ was added to the reaction mixture followed by extraction with $\mathrm{Et}_{2} \mathrm{O}(2 \times 5 \mathrm{~mL})$. The collected organic fractions were dried with $\mathrm{MgSO}_{4}$ and filtered. Evaporation of the solvent in vacuo yielded $0.15 \mathrm{~g}$ of a colourless oil. ${ }^{1} \mathrm{H}$ NMR $\left(\mathrm{CDCl}_{3}, 25^{\circ} \mathrm{C}\right): \delta 1.25\left(\mathrm{~s}, 6 \mathrm{H}, \mathrm{CH}_{3}\right), 2.11(\mathrm{~s}, 1 \mathrm{H}, \mathrm{OH}), 2.25$ $\left(\mathrm{d}, 2 \mathrm{H},{ }^{3} \mathrm{~J}_{\mathrm{HH}}=8.0 \mathrm{~Hz}, \mathrm{CH}_{2}=\mathrm{CHCH}_{2}\right), 4.95-5.17(\mathrm{~m}, 2 \mathrm{H}$, $\left.\mathrm{CH}_{2}=\mathrm{CHCH}_{2}\right), 5.71-5.88\left(1 \mathrm{H}, \mathrm{m}, \mathrm{CH}_{2}=\mathrm{CHCH}_{2}\right)$. GCMS analysis $100\left(1, \mathrm{M}^{+}\right), 85\left(10, \mathrm{M}^{+}-\mathrm{CH}_{3}\right), 59(100), 43$ (55, $\mathrm{M}^{+}-\mathrm{C}_{3} \mathrm{H}_{5}$ ), 31 (22) (2-methyl-4-pentene-2-ol).

4.1.6. Reactions of $\mathrm{MZ}_{2}$ (bipy) $(\mathrm{M}=\mathrm{Pd}, \mathrm{Pt} ; \mathrm{Z}=\mathrm{Me}, \mathrm{Cl})$ with 3-chloropropene or $\mathbf{S n C l}_{2}$. All experiments were performed with $0.4 \mathrm{mmol}$ of platinum- or palladium complex and $\mathrm{SnCl}_{2}$ (302 mg, $1.6 \mathrm{mmol}$ ) or 3-chloropropene $(122 \mathrm{mg}, 1.6 \mathrm{mmol})$ in $10 \mathrm{~mL}$ of $\mathrm{CH}_{2} \mathrm{Cl}_{2}$. The reaction mixtures were analyzed by ${ }^{1} \mathrm{H}$ NMR spectroscopy with $\mathrm{CDCl}_{3}$ or acetone- $d_{6}$ as solvent.

4.1.7. Stoichiometric reaction of $\mathrm{PdMe}_{2}(\mathrm{bipy})$ with 3-chloropropene and $\mathbf{S n C l}_{2}$. To a mixture of 3-chloropropene $(3 \mu \mathrm{L}, 0.032 \mathrm{mmol}), \mathrm{SnCl}_{2}(6 \mathrm{mg}, 0.032 \mathrm{mmol})$ and $\mathrm{CD}_{2} \mathrm{Cl}_{2}(0.5 \mathrm{~mL})$ in a NMR tube, $\mathrm{PdMe}_{2}$ (bipy) (10 mg, $0.032 \mathrm{mmol}$ ) was added. The tube was stored at room temperature and the solution was analysed by ${ }^{1} \mathrm{H}$ NMR spectroscopy at regular intervals.

4.1.8. Decomposition of $\left[\mathrm{PtMe}_{2}(\mathrm{allyl})\left(\mathrm{SnCl}_{3}\right)(\mathrm{bipy})\right]$ (3). A solution of $16 \mathrm{mg}(0.024 \mathrm{mmol})$ of 3 in $1 \mathrm{~mL}$ of acetone$d_{6}$ was transferred. After the tube was sealed, it was submerged in a oil bath at $60^{\circ} \mathrm{C}$ for 2 days. The NMR-tube was cooled to room temperature and the solution was analysed by ${ }^{1} \mathrm{H}$ NMR spectroscopy at regular intervals. After $48 \mathrm{~h}$, an orange solid had precipitated from the solution. ${ }^{1} \mathrm{H}$ NMR (acetone- $\left.d_{6}, 25^{\circ} \mathrm{C}\right): \delta 2.19\left(\mathrm{~d}, 2 \mathrm{H}, \mathrm{CH}_{2}\right.$, $\left.{ }^{3} J_{\mathrm{HH}}=5.0 \mathrm{~Hz}\right), 4.96-5.10\left(\mathrm{~m}, 2 \mathrm{H}, \mathrm{CH}_{2}\right), 5.81-6.02(\mathrm{~m}, 1 \mathrm{H}$, $\mathrm{CH}$ ). An independently prepared sample of (allyl) $\mathrm{SnCl}_{3}{ }^{4 \mathrm{~b}}$ showed the same resonances in the ${ }^{1} \mathrm{H}$ NMR spectrum recorded in acetone- $d_{6}$.

\section{References}

1. Ayrey, G.; Head, B. C.; Poller, R. C. Macromol. Rev. 1974, 8, $1-49$.

2. Evans, C. J. In Chemistry of Tin; Harisson, P. G., Ed.; Blackie: Glasgow, 1989; pp 421-453.

3 (a) Bokranz, A.; Plum, H. Fortschr. Chem. Forsch. 1971, 16, 365-403. (b) Moedritzer, K. Organomet. Chem. Rev. 1966, 179-278. (c) Ingham, R. K.; Rosenberg, S. D.; Gilman, H. Chem. Rev. 1960, 60, 459-539. 
4. (a) Fishwick, M.; Wallbridge, G. H. J. Organomet. Chem. 1970, 25, 69-79. (b) Naruta, Y.; Nishigaichi, Y.; Maruyama, K. Tetrahedron 1989, 45, 1067-1078. (c) Denmark, S. E.; Wilson, T.; Willson, T. M. J. Am. Chem. Soc. 1988, 110, 984-986.

5. (a) Seyferth, D.; Stone, F. G. A. J. Am. Chem. Soc. 1957, 79, 515-517. (b) Rosenberg, S. D.; Gibbons, A. J., Jr. J. Am. Chem. Soc. 1957, 79, 2137-2138.

6. (a) Zimmer, H.; Sparmann, H.-W. Chem. Ber. 1954, 87, 645-651. (b) Gilmann, H.; Gist, L. A., Jr. J. Org. Chem. 1957, $22,368-371$.

7. Thoonen, S.; Deelman, B.-J.; van Koten, G. Chem. Commun. 2001, 1840-1841.

8. (a) Pfeifer, R.; Heller, I. Chem. Ber. 1904, 37, 4618. (b) Bulten, E. J. J. Organomet. Chem. 1975, 97, 167-172. (c) Bulten, E. J.; Gruter, H. F. M.; Martens, H. F. J. Organomet. Chem. 1976, 117, 329-338.

9. Masuyama, Y. Adv. Met.-Org. Chem. 1994, 3, 255-303.

10. Lorberth, J.; Vahrenkamp, H. J. Organomet. Chem. 1968, 11, $111-124$

11. Takahara, J. P.; Masuyama, Y.; Kurusu, Y. J. Am. Chem. Soc. 1992, 114, 2577-2586.

12. The ${ }^{1} \mathrm{H}$ NMR data of the product corresponded with the values reported for allyltin tribromide. See Fishwick, M. F.; Wallbridge, M. G. H. J. Organomet. Chem. 1977, 136, C46-C48.

13. Neumann, W. P. The Organic Chemistry of Tin; Wiley: New York, 1967.

14. Ul Hasan, M.; Tsonis, C. P. J. Polym. Sci. 1984, 22, $1349-1355$.

15. (a) Albeck, M.; Tamari, T. J. Organomet. Chem. 1982, 238, 357-362. (b) Arata, K.; Fukui, A.; Toyoshima, I. J. Chem. Soc., Chem. Commun. 1978, 121-122.

16. Hirako, K.; Miyamoto, Y.; Kakiuchi, K.; Kurosawa, H. Inorg. Chim. Acta 1994, 222, 21-25.

17. Paiaro, G.; Musco, A. Tetrahedron Lett. 1965, 6, 1583-1586.

18. Byers, P. K.; Canty, A. J.; Traill, P. R.; Watson, A. A. J. Organomet. Chem. 1990, 390, 399-407.

19. Coddington, J. M.; Taylor, M. J. J. Chem. Soc., Dalton Trans. 1989, 2223-2227.

20. Musco, A.; Pontellini, R.; Grassi, M.; Sironi, A.; Meille, S.; Rüegger, H.; Ammann, C.; Pregosin, P. S. Organometallics 1988, 7, 2130-2137.

21. Lopez, C.; Gonzalez, A. S.; Garcia, M. E.; Casa, J. S.; Sordo, J. J. Organomet. Chem. 1992, 434, 261-268.

22. Monaghan, P. K.; Puddephatt, R. J. Organometallics 1984, 3, 444-449.
23. Kuyper, J. Inorg. Chem. 1978, 17(1), 77-81.

24. Thoonen, S. H. L.; Deelman, B.-J.; van Koten, G. Organometallics 2003, 22, 1156-1159.

25. (a) Brown, M. P.; Puddephatt, R. J.; Upton, C. E. E.; Lavington, S. W. J. Chem. Soc., Dalton Trans. 1974, 1613-1618. (b) Appleton, T. G.; Berry, R. D.; Hall, J. R.; Neale, D. W. J. Organomet. Chem. 1988, 342, 399-422. (c) de Graaf, W.; Boersma, J.; van Koten, G. Organometallics 1990, 9, 1479-1484. (d) Peters, R. G.; White, S.; Roddick, D. M. Organometallics 1998, 17, 4493-4499.

26. (a) Appleton, T. G.; Clark, H. C.; Manzer, L. E. J. Organomet. Chem. 1974, 65, 275-287. (b) Baar, C. R.; Jenkins, H. A.; Vittal, J. J.; Yap, G. P. A.; Puddephatt, R. J. Organometallics 1998, 17, 2805-2818. (c) De Felice, V.; Giovannitti, B.; De Renzi, A.; Tesauro, D.; Panunzi, A. J. Organomet. Chem. 2000, 593-594, see also 445-453.

27. (a) Ruegg, H. J.; Pregosin, P. S.; Scrivanti, A.; Toniolo, L.; Botteghi, C. J. Organomet. Chem. 1986, 316, 233-241. (b) Holt, M. S.; Wilson, W. L.; Nelson, J. H. Chem. Rev. 1989, 89, 11-49, and references therein. (c) Farkas, E.; Kollár, L.; Moret, M.; Sironi, A. Organometallics 1996, 15, 1345-1350. (d) Deibele, C.; Permin, A. B.; Petrosyan, V. S.; Bargon, J. Eur. J. Inorg. Chem. 1998, 1915-1923.

28. Chaudhury, N.; Puddephatt, R. J. J. Organomet. Chem. 1975, $84,105-115$.

29. Newkome, G. R.; Theriot, K. J.; Fronczek, F. R.; Villar, B. Organometallics 1989, 8, 2513-2523.

30. Almeida, J. F.; Azizian, H.; Eaborn, C.; Pidcock, A. J. Organomet. Chem. 1981, 210, 121-133.

31. Watt, G. W.; Cuddeback, J. E. J. Inorg. Nucl. Chem. 1971, 33, 259-263.

32. Fox, S. G.; Gillard, R. D. Polyhedron 1988, 7, 349-352.

33. Byers, P. K.; Canty, A. J. Organometallics 1990, 9, 210-220.

34. Newkome, G. R.; Gupta, V. K.; Taylor, H. C. R.; Fronczek, F. R. Organometallics 1984, 3, 1549-1554.

35. de Graaf, W.; Boersma, J.; Smeets, W. J. J.; Spek, A. L.; van Koten, G. Organometallics 1989, 8, 2907-2917.

36. Herwig, J.; Keim, W. Inorg. Chem. Acta 1994, 222, 381-385.

37. Kharasch, M. S.; Seyler, R. C.; Mayo, F. R. J. Am. Chem. Soc. 1938, 60, 882-884.

38. Tellier, F.; Sauvetre, R.; Normant, J.-F. J. Organomet. Chem. 1985, 292, 19-28.

39. Fishwick, M.; Wallbridge, G. H. J. Organomet. Chem. 1970, 25,69 .

40. The value of $69.8 \mathrm{~Hz}$ is typical for a ${ }^{3} J_{\mathrm{CSn}}$ coupling constant Al-Allaf, T. A. K. J. Organomet. Chem. 1986, 306, 337-346. 